\title{
OS IMIGRANTES ALEMÃES E SEUS DESCENDENTES NO BRASIL:A LİNGUA COMO FATOR IDENTITÁRIO E INCLUSIVO
}

\author{
Karen Pupp Spinassé \\ Universidade Federal do Rio Grande do Sul
}

Resumo: O passado do Brasil como colônia portuguesa desenhou o desenvolvimento da história e da gente brasileira. Entretanto, as ondas migratórias de outros povos europeus também exerceram função inquestionável na formação da diversidade lingüística, étnica, social, cultural e política característica do país. Os imigrantes alemães no Brasil, por exemplo, sofreram muitas vezes, durante o processo de adaptação e modificação (tanto de seu dia-a-dia como de sua língua), com aspectos negativos próprios de minorias estrangeiras: a exclusão identitária e o preconceito. Junto a razões geográficas e históricas, também fatores sociais contribuíram para esse quadro. $O$ presente artigo visa a descrever esse processo através da lingüística, observando as fases distintas pelo qual passou. Como base, exemplo e fonte foram utilizadas pesquisas sobre o alemão falado atualmente no Brasil, traçando assim uma ligação direta entre língua, identidade e integração social. O trabalho mostrará como os fatores lingüísticos influenciaram e marcaram o processo integrativo.

Palavras-chave: identidade, variação lingüística, integração social, hunsrückisch

\begin{abstract}
The Portuguese colonization with its system was the central line of Brazil's socioanthropological development. However, the migrations waves from other Europeans have also influenced at the construction of Brazil's typical linguistic, ethnical, social, cultural and political diversity. As one of these, the German immigrants in Southern-Brazil suffered some times during the process of adaptation and modification (so well in their day-by-day life as in their language) the negative aspects of a foreign minority: the identity exclusion and the discrimination. Not just the geographical and historical reasons, but the social factors did also help to such a situation. Therefore, this paper intends to describe this process through the linguistic, observing the different periods it passed through. This analysis was driven by researching the "German"-Language spoken nowadays in Brazil, making a direct relationship among language, identity and social integration. This paper shows, how the language influenced and characterized the integrations process.
\end{abstract}

Keywords: identity, linguistic changes, social integration, hunsrückisch

\section{Introdução}


A língua materna caracteriza o indivíduo e está intimamente ligada à sua identidade. Por esse motivo, a Primeira Língua (L1) é de extrema importância para uma pessoa: ela age como uma manifestação identitária pessoal e intrínseca ao indivíduo. A nossa L1 nos caracteriza na sociedade, também pelo modo como a usamos e quão bem a dominamos. Entre falantes nativos de uma mesma língua é possível, por exemplo, deduzir a naturalidade, o grau de instrução e até mesmo o nível social do falante apenas através da língua, da modalidade lingüística.

Para um estrangeiro, em uma sociedade que não é a sua, a língua desempenha, além disso, uma função dual muito clara: ela pode agir como o ponto crucial do processo de integração daquele indivíduo nesta sociedade, através da tentativa por parte dele de aprender a nova língua e falá-la satisfatoriamente no que diz respeito à comunicação; todavia, o fator lingüístico pode afastar ainda mais as realidades já distintas, servindo como ponto de atrito, causador de dificuldades, e consequientemente, como fator de exclusão. Como, ou mesmo "se" o estrangeiro aprende a nova língua, mostra o quão profundamente ele pode se integrar e quão bem ele pode ser aceito pelos nativos - ou não. ${ }^{1}$

O presente artigo trata dessa problemática no seguinte aspecto: os imigrantes alemães se estabeleceram no Brasil na primeira metade do século XIX, confrontando-se com uma sociedade "estranha" a eles, que possuía uma língua - e um sistema lingüístico - completamente desconhecidos para a grande maioria. Através de uma perspectiva lingüística, gostaríamos de entrar na questão da dicotomia Exclusão/Integração na história da imigração alemã no Brasil, dentro do processo de formação identitária. Para isso, lançamos mão de ótimas pesquisas abrangentes sobre as colônias alemãs no Brasil ${ }^{2}$, assim como de resultados de aspectos levantados em duas regiões. O tema da imigração alemã no Brasil já foi muito trabalhado e discutido. Pretende-se, entretanto, permear o processo de integração na identidade "brasileira" com enfoque na influência linguiística, percebendo as fases mais excludentes e mais inclusivas pelas quais os imigrantes passaram e que tiveram a língua como principal elemento.

A autora tem como objeto de estudo a questão lingüística e, principalmente, a questão da didática e do ensino do alemão no Brasil. O presente artigo é, entretanto, a tentativa de compartilhar reflexões a respeito da delimitação da evolução da história através de características da evolução lingüística. A grande pretensão desse texto é tratar dessa relação. A língua, afinal, sempre exerceu uma função determinante no processo de integração social, e esse será o foco do presente artigo. Para tanto, dividimos o conteúdo de forma cronológica: inicia-se com os imigrantes propriamente ditos e finaliza-se com a geração atual de descendentes, para traçar um perfil histórico do processo de mudança lingüística. No final, serão tecidos comentários sobre os diferentes aspectos da convivência dos imigrantes na "nova" sociedade com uma visão abrangente sobre as fases descritas.

\section{1- Da História - O Início da Imigração}

\footnotetext{
${ }^{1}$ Vide Mues 1970

${ }^{2}$ Altenhofen 1996, Tornquist 1997, Ziegler 1996
} 
Alemães emigraram para o Brasil por variados motivos, mas com um único objetivo: o de iniciar aqui uma vida nova e melhor. A pobreza predominava na Alemanha e os governos ${ }^{3}$ não davam conta de auxiliar e amparar a população. Essa situação emergencial era grave e muitas pessoas passavam fome. Além disso, as perseguições religiosas, o sistema agrícola ainda muito marcado pelo feudalismo e o alto índice de natalidade entre os camponeses levavam a graves problemas, como a falta de emprego, e a sérias crises no caso de uma má colheita, como ocorreu nos anos de 1816/17 no estado de Baden.

Por sua vez, o Brasil, como um país jovem e de independência recém-declarada, necessitava de mais habitantes e de mais mão-de-obra para o imenso território. Somado a isso, o imperador D. Pedro intentava formar um exército com soldados europeus, uma vez que Portugal ainda não havia reconhecido a independência da antiga colônia, e ele via, com isso, a necessidade de preparar resistência armada para o caso de uma invasão. O governo brasileiro enviou, então, agentes de imigração para a Europa, para fazerem propaganda sobre o Brasil. A divulgação dessas possibilidades de imigração no Brasil deu-se principalmente nos estados alemães e na Suíça. Assim, levaram esperança ao povo alemão, motivando-o com informações e promessas. Segundo Dreher (1984), foi feita muita propaganda falsa sobre o país-destino, a qual o governo brasileiro desconhecia, e que até mesmo feria a constituição brasileira da época. ${ }^{4}$ Os alemães, no seu estado de pobreza, acreditavam, contudo, em tudo o que lhes era informado, e davam tudo o que tinham para pagar a viagem marítima, colocando-se a caminho do "Eldorado".

Assim os alemães entraram no Brasil e queriam iniciar aqui sua nova vida. Segundo Seyferth (1994), a grande maioria desses imigrantes não tinha a intenção de regressar para a Alemanha. Primeiro, eles sabiam que a volta seria muito difícil e muito cara; segundo, não valia a pena, uma vez que a situação emergencial na Europa não mudaria de uma hora para a outra e, uma vez lá, voltariam a viver em condições precárias; e terceiro, a grande maioria já chegou no seu destino com a idéia de fazer do Brasil a sua nova "terra natal", ou seja, de realmente assumir a cidadania brasileira. ${ }^{5}$

No início do século XIX já haviam sido fundadas colônias alemãs na região nordeste e sudeste do Brasil, mas essas "não tiveram êxito". ${ }^{6}$ Como data oficial para o início da Imigração Alemã no Brasil, tem-se, então, o dia 25 de julho de 1824, que todo ano é comemorado em várias localidades onde houve imigração alemã. Essa data marca, na verdade, o momento em que imigrantes alemães chegaram ao Rio Grande do Sul. Do Rio de Janeiro, os imigrantes eram mandados primeiramente para o sul do Brasil, pois exatamente esta região precisava ser povoada, para que os limites fronteiriços com os

\footnotetext{
${ }^{3}$ No início do século XIX, a Alemanha ainda não constituía um Estado, uma unidade política, como conhecemos hoje. Uma Federação Alemã, dividida em estados independentes regionais, formou-se após o Congresso de Viena, em 1815. Ela era formada pelo Império Austríaco, por cinco Reinados (Prússia, Baviera, Saxônia, Hannover e Württemberg), um Eleitorado (Hessen), 18 Ducados e Grão-Ducados, 13 Principados e quatro cidades (vide Reinhardt Rürup 1984, 127).

${ }^{4}$ Vide Dreher 1984, 31

${ }^{5}$ Vide Seyferth 1994, 16

${ }^{6}$ Fala-se de "não-êxito" das colônias anteriores a 1824, pois elas não resguardaram as características originais de "colônia", que prevê o trabalho rural e comunitário. Schaden/Willems/Hehl Neiva se valem do artigo 46 da lei 7967 de 18 de setembro de 1945 para ratificar a idéia. Reproduzimos aqui o parágrafo: “Art. 46 - Colonizar é promover a fixação do elemento humano ao solo, o aproveitamento econômico da região e a elevação do nível de vida, saúde, instrução e preparo técnico dos habitantes das zonas rurais". (Em Schaden/Willems/Hehl Neiva 1963, 357)
} 
países hispânicos fossem assegurados e resguardados (o risco de uma invasão pela Argentina era grande, justamente por a região ser tão pouco povoada e de difícil controle para o governo devido à sua distância).

Os imigrantes não encontraram, entretanto, os campos vastos prometidos, com casa, animais, sementes e árvores frutíferas, mas sim áreas de mata virgem, que tiveram que desbravar. Assim, foram criadas no sul várias comunidades distintas e independentes. Cada grupo de imigrantes que chegava junto e abria uma clareira na mata para si, permanecia, normalmente, junto. Em torno dessas pequenas comunidades não havia, geralmente, nenhum outro grupo de pessoas. Por esse motivo, existia no início pouco contato com "brasileiros", ou com outros grupos de imigrantes. Eles viveram, por muito tempo, isoladamente. ${ }^{8}$

\section{2- A Primeira Fase}

Os moradores dessas comunidades geralmente não vinham dos mesmos lugares no território alemão. Havia entre eles prussianos, pomeranos, austríacos, suíços, renanos, bávaros etc., que trouxeram consigo seus respectivos dialetos. Como dito anteriormente, ainda não havia uma Alemanha unida politicamente - a unificação alemã veio apenas em 1871 - e as características regionais eram mais distintas nos hábitos, costumes e, principalmente no que diz respeito à língua. Apesar da existência de um alemão-padrão relativamente bem disseminado, as variações lingüísticas de uma região para a outra eram muito grandes. O que neste artigo se denomina como "alemão", "língua alemã" refere-se mais a um campo linguístico teuto, do que àquilo que entendemos hoje com os mesmos termos.

A primeira assimilação concreta por parte dos imigrantes de língua alemã em solo brasileiro deu-se, então, com um outro elemento da língua alemã, heterogêneo, contudo, sob o aspecto lingüístico. ${ }^{9}$ Como os dialetos eram diferentes, a variedade da maioria geralmente se impunha. Em várias regiões, foi esse o caso. A maioria dos imigrantes vinha da região mais pobre da Alemanha naquela época, a região do Hunsrück, e sua língua materna era o dialeto francônio-renano. Nem todos os habitantes originais das colônias estudadas vinham da citada região alemã, mas praticamente desde o início de sua vida no Brasil eles assimilaram o dialeto de lá, por "imposição" da maioria. Isso ocorreu em várias comunidades, com variedades dialetais diferentes, que sofreram o mesmo processo inicial. Essa assimilação marca também o início da mudança e da variação linguiística entre eles, pois sempre se acrescentam elementos próprios a uma língua emprestada.

Especialmente na primeira fase, as colônias eram muito semelhantes a "ilhas". Essa realidade contribuiu para que as variedades lingüísticas alemãs se desenvolvessem de maneira forte e se mantivessem presentes nas comunidades, embora não houvesse mais, por parte da grande maioria, nenhuma ligação com a Alemanha.

\footnotetext{
${ }^{7}$ Por "brasileiro" entende-se o descendente de português, o nativo que domina sem restrições o idioma português.

${ }^{8}$ Ver também Neumann 2000, Seyferth 1994

${ }^{9}$ Vide Seyferth 1994
} 
Segundo historiadores e outros estudiosos, o governo brasileiro não dava aos imigrantes o suporte necessário. Eles próprios tinham que organizar escolas e igrejas, conseguir professores e pastores, e construir os centros comunitários, para que assim pudessem estabelecer uma estrutura social normal. Assim, sem subsídio por parte das autoridades brasileiras, não se ensinava português na colônia. As aulas eram ministradas na variante local. Da mesma forma, os cultos religiosos nas comunidades eram em alemão, já que o pastor era um dos "alemães" e sua língua a mesma da comunidade. Eles praticamente não precisavam sair da colônia, pois tinham lá tudo o que precisavam para a vida dentro dessa ilha lingüística.

A língua exerceu aí uma função muito importante: através dela, ou melhor, através da homogeneidade lingüística dentro das comunidades, garantiu-se uma sobrevivência na fase inicial no país desconhecido, assim como o sucesso das colônias. Embora nesse momento ainda não se perceba um processo de integração ativa na sociedade brasileira, a língua local significava, entre eles, sem dúvida nenhuma, um fator de integração. $\mathrm{Na}$ história da imigração alemã no Brasil, a língua não era ainda, nessa primeira fase, um fator de exclusão, até porque o contato com falantes do português era menor. A divisão territorial se punha mais contra a integração do que a própria língua, já que eles viviam afastados dos demais. No entanto, esses imigrantes pertenciam à sociedade brasileira como um todo e já demonstravam o desejo e a intenção de participar mais ativamente das questões nacionais. Carneiro (1963) lembra isto em um discurso, no qual ele cita a carta de Duque de Caxias ao governo imperial em 12 de dezembro de 1824. A carta dizia:

Ilmo. e Exmo. Sr. Estive ontem na colônia de São Leopoldo e fiquei satisfeitíssimo de ver o estado dela. Esta colônia pacífica e industriosa abastece a capital da Província de todos os gêneros necessários à vida. Sua exportação mensal regula a 18 contos de réis. Os colonos reclamam ardentemente ser reconhecidos cidadãos brasileiros, conforme o trato com êles feito, que por cópia inclusa remeto. (...) Êles se entristecem com a lembrança de que o G.I. [governo imperial] concedesse o título de nossa nacionalidade aos da colônia do Sahi, entretanto que êles, antigos, prestantes e cheios de filhos, que já servem ao país que os viu nascer, estão privados dêste gôzo. ${ }^{10}$

O sentimento de pertencimento acima não significou ainda, nessa fase, uma integração lingüística na sociedade brasileira propriamente dita. Se em um primeiro momento dessa primeira fase os imigrantes preocuparam-se, principalmente, em integrar-se em comunidade para poderem construí-la (casas, centros comunitários, escola, igreja...), o contato com falantes do português era superficial e secundário. Nas cidades, onde o contato era mais intenso, a assimilação lingüística era mais fácil e rápida. No interior, entretanto, sem um contato significante com falantes do português, as diferenças lingüísticas e culturais dificultavam ainda mais esse início no processo de integração lingüística. ${ }^{11}$ Com o passar dos anos, isso vai se tornando mais claro, como veremos a seguir.

\section{3- O Desenvolvimento do Processo Lingüístico}

\footnotetext{
${ }^{10}$ Em: Carneiro 1963, 25

${ }^{11}$ Vide Rambo 1994, 11
} 
Em uma segunda fase (lê-se em torno da década de 70 do século XIX), a realidade lingüística dos imigrantes alemães no Brasil já havia mudado de situação: outros grupos de imigrantes - principalmente de italianos - vieram para o sul do Brasil. Além disso, nesse momento, também "brasileiros" já povoavam mais intensamente a região. No entanto, a trajetória dos imigrantes alemães no Brasil até então os havia levado a permanecerem fechados em suas colônias. Como já foi dito, eles conseguiram construir uma estrutura independente e auto-suficiente, que os mantinha na segurança da colônia. Lá, as pessoas conseguiam se entender e se fazer entender, o que seria muito difícil de conseguir com os vizinhos.

Os novos vizinhos representavam um "corpo estranho" no mundo dos imigrantes, com o qual eles ainda teriam que aprender a lidar. O comércio com "brasileiros" e demais estrangeiros já era maior e mais intenso, uma vez que os comerciantes vinham mais até as colônias vender seus produtos. As primeiras gerações de imigrantes já tiveram que estabelecer contato com comerciantes de fora da colônia, mas isso não acontecia tão freqüentemente, até pelo seu padrão de vida não ser tão alto. $O$ português era tido como língua muito difícil, e aquele que o aprendia tinha um prestígio maior dentro da colônia, era visto, praticamente, como "citadino", e representava a colônia fora dela. A língua oficial do país não era, necessariamente, um fator de sobrevivência para cada um.

Nessa nova fase, contudo, a língua nacional se aproxima mais, começa a se tornar algo palpável e, assim, elemento indispensável para o comércio, as negociações e para a inserção no quadro social como cidadão ativo politicamente. Com isso, ela também se tornou, muitas vezes, um problema. Os "teuto-brasileiros" não conseguiam se integrar tão facilmente com os vizinhos. A partir de então se inicia uma tentativa maior de aprender o português. Nesse momento, certamente surgiram muitos questionamentos em relação à própria identidade: por que falavam alemão, se não eram alemães. Especula-se que problemas de identidade e confrontos de gerações devam ter ocorrido, pois na opinião dos pais, a língua, que graças ao isolamento tinha sido mantida como um fator identitário, era a responsável por manter uma ligação com a pátria abandonada. No entanto, para a juventude, essa "nostalgia" não fazia muito sentido. Eles já tinham uma pátria, no caso, o Brasil. ${ }^{12}$

Depois de muitos anos de vida numa ilha lingüística não seria fácil aprender uma outra língua de forma natural. Eles tentavam constituir um contato mais próximo com os vizinhos, mas o seu português saía com sotaque e nem sempre entendível. Seu vocabulário também era extremamente limitado, pois não havia tido contato com o português anteriormente. Como afirma Peloso (1991), "para a definição de uma identidade própria, é necessário não só uma língua própria, mas também o olhar do outro". ${ }^{13}$ Devido ao sotaque e a todas as dificuldades de se expressarem no idioma nacional, embora eles tentassem aprender a língua, do ponto de vista dos brasileiros eles eram apenas "os alemães". Apesar de uma parte, provavelmente, não querer mais ser vista como "alemão", o olhar dos "brasileiros" sempre contou para o sucesso, assim como para o insucesso dessa integração.

Essa diáspora acompanhou as novas gerações: por um lado, eles não conseguiam se desvencilhar de sua tradição, de sua língua materna - e nem o queriam; por outro lado, eles não queriam mais ser vistos como "estrangeiros", "estranhos", pois também não o eram. Seyferth esclarece bem esse paradoxo identitário: “(...) é a língua oficial do

\footnotetext{
${ }^{12}$ Ver também Seyferth 1981, Neumann 2000

${ }^{13}$ Peloso 1991, 167
} 
país, e por isso torna-se necessário aprendê-la como uma das obrigações de cidadãos brasileiros, mas não usá-la em comunidade, porque traria prejuízos irreparáveis ao Deutschtum". ${ }^{14}$

Do ponto de vista da teoria dos Estudos Culturais, este seria um caso de "identidade híbrida": eles são "teuto-brasileiros". Seyferth define o termo da seguinte maneira: "Ainda têm a língua alemã como materna, tenham eles nascido suíços, brasileiros, austríacos, russos, alemães... mas têm sua pátria no Brasil. (...) Considera-se membro de uma comunidade étnica alemã, mas a lealdade política pertence ao Brasil e não à Alemanha". ${ }^{15}$ As novas gerações viviam no limite entre dois mundos, e através disso iniciou-se algo como uma fase mista, mesmo no que diz respeito à língua: o português vinha agora com mais freqüência ao encontro dos teuto-brasileiros, e a língua alemã não era mais "intocável”.

Era notório que o aprendizado do português marcava o início para o processo de integração, apesar de a vergonha por falar mal o português - e o conseqüente preconceito lingüístico por parte dos "brasileiros" - agirem a favor do fechamento e do resguardo. Não só em estudos da sociologia, da antropologia e da história encontram-se tais afirmações, mas também em estudos das Ciências da Literatura perceberam-se apontamentos sobre isso. Neumann (2000) pesquisou manifestações sobre a integração de imigrantes alemães e descendentes no Brasil em produções literárias, e concluiu que muitos se engajavam na sociedade. A integridade da língua alemã entre os imigrantes alemães luteranos e seus descendentes esteve muito comprometida na segunda metade do século XIX, de modo que o pastor evangélico Wilhelm Rotermund foi enviado para o Brasil para restabelecer a manutenção da língua alemã e "salvar o Deutschtum". ${ }^{16}$

A Nacionalização, outorgada em 1937 pelo presidente Getúlio Vargas no Brasil, auxiliou, pelo menos em parte, para esse processo de assimilação da língua portuguesa. Nesse momento foi acentuada a importância de se caracterizar a nação brasileira. A língua portuguesa tornou-se mais forte e mais presente nas colônias, pois com a nacionalização "todo o meio-escolar teuto-brasileiro (...) em todo o Brasil foi destruído". ${ }^{17}$ As aulas nas escolas coloniais eram até então ministradas em alemão, mas, a partir da nacionalização, isso fica terminantemente proibido. Anos letivos são perdidos, já que os alunos não dominam o português a ponto de assistirem as aulas com os novos professores enviados pelo governo.

Logo em seguida, em decorrência da Segunda Guerra Mundial, a língua alemã é proibida no Brasil. Como o historiador francês Jean Roche define, foi proibido publicar jornais em língua alemã, assim como falar alemão em lugares públicos; documentos alemães foram retirados de residências e apreendidos; bibliotecas alemãs foram destruídas; as armas das sociedades de tiro foram tomadas; houve prisões e internações. ${ }^{18}$ Certamente os colonos não pararam de falar alemão nas colônias - os mais velhos nem saberiam falar em outra língua. Esse processo contribuiu, porém, para que mais elementos da língua portuguesa se misturassem à suas línguas maternas, e para que eles se apegassem ainda mais aos dialetos locais, legitimando a sua transformação e seu uso. Cada vez mais distante do Hochdeutsch (o alemão-padrão), ele começava a se caracterizar como dialeto autônomo, sem uma língua-teto a se subordinar.

\footnotetext{
${ }^{14}$ Deutschtum é um termo alemão que alguns autores traduzem para "patrimônio cultural alemão" (ver Neumann 2000, 117 e Huber 1993, 37). Citação de Seyferth 1981, 83

${ }^{15}$ Seyferth 1981,74

${ }^{16}$ Vide Neumann 2000

${ }^{17}$ Ziegler 1996, 40

${ }^{18}$ Vide Roche 1969, 719
} 
Tem que se levar em consideração também, que muitos começaram a sentir vergonha e medo de serem "alemães", devido a traumas desta época de guerra, e não queriam mais, por opção própria, falar alemão. De integração, porém, ainda não se pode classificar esse processo. Embora no âmbito da língua tenham acontecido mudanças perceptíveis, a situação proveniente da proibição da língua alemã interrompe - mesmo que apenas por um certo período - o contato com o "mundo exterior" à colônia. A proibição da língua alemã e a discriminação em relação aos colonos os levavam de volta ao isolamento - claro que em outro nível. Isso significou de qualquer forma uma perda no processo de integração, pois dessa vez eles foram excluídos não por não falarem o português, mas pelo simples fato de dominarem uma outra língua, especificamente, o alemão, como L1.

Após a paulatina superação dos problemas do período de guerra, o processo de integração continua. Elementos da língua portuguesa continuam aparecendo nas variações dialetais das regiões de imigração alemã, continuamente e por causa dos acontecimentos citados. A nova geração aprende assim a sua língua materna: é alemão, mas também tem características do português. Esses falantes, que são tidos como "alemães" por não falarem bem o português e terem ascendência e sotaque germânicos, percebem que também não falam a língua do indivíduo que vem da Alemanha, e que muitas palavras são empréstimos do português. Tendo identidade híbrida (teutobrasileira), mas sendo tratados como "estrangeiros" pelas duas sociedades as quais acham pertencer, os próprios falantes agem de preconceito lingüístico com sua língua materna - daí os conceitos "alemão errado" e "língua misturada".

Mesmo assim, a língua se faz presente, pois mesmo não sendo nem um idioma oficial nem o outro, é essa variante dialetal que os caracteriza enquanto indivíduos de identidade híbrida (mesmo inconscientemente). Apesar de a aula ser em língua portuguesa, essa variedade "mista" é ouvida nas escolas, nas casas e na comunidade. Esses jovens teuto-brasileiros vão mais aos grandes centros e lá também se fala o português, que a partir da década de 70 também invade as casas de colonos através da televisão. Através desse contato maior com o português, eles o aprendem de forma mais natural. Essa língua entra agora em casa e - inevitavelmente - continua a entrar nas suas variantes lingüísticas maternas.

Disso originou-se, praticamente, um terceiro sistema lingüístico, peculiar e com características próprias, mantendo uma base alemã e elementos derivados de empréstimos. Esse tipo de variedade lingüística, que se desenvolveu a partir do contato linguiístico principalmente do português com um registro dialetal alemão, mas que seguiu (e segue até hoje) um processo de evolução lingüística natural interno. Dependendo da base dialetal de maior influência, ou seja, de acordo com o dialeto original adotado pela colônia antes das variações, a variante recebe hoje sua nomenclatura. Por isso fala-se hoje de Pommerisch (pomerano), Westfällisch (vestfaliano), entre outras. Elas remetem através da denominação ao dialeto de partida, por mais diferentes que estejam hoje.

No caso das colônias pesquisadas pela autora, o dialeto alemão predominante foi o da região do Hunsrück (dialeto francônio-renano). O que Ziegler (1996), por exemplo, denomina "Misturado", devido ao caráter misto apresentado pela variante, Altenhofen (1996) chama de "hunsrückisch", por remeter à língua base de origem e por ser o termo utilizado pelos próprios falantes para designarem o seu idioma. Damos preferência à denominação de Altenhofen, primeiro por caber num mesmo paradigma com as outras variantes, e segundo por sabermos que a mistura não é o único fator de formação das variantes dialetais de base francônio-renana (e nem é a única que contou com misturas 
para a sua formação atual. $\mathrm{Na}$ verdade, qual língua não possui empréstimos e estrangeirismos em seus diferentes campos gramaticais?). Mesmo abordando no próximo ponto a questão da mistura para tratar de forma ilustrativa o processo de integração social e identitária, o termo empregado por Ziegler limitaria as características do hunsrückisch somente a esse aspecto, o que deve ser evitado.

\section{4- O Hunsrückisch como um Marco de Integração}

Não se pode ignorar que a base dessa variante lingüística foi, verdadeiramente, o dialeto francônio-renano, ou seja, que seus elementos são os que foram mantidos em maior número. Por esse motivo, nem todos os desvios nas variantes do alemão no sul do Brasil são influência do português, como muitos pensam. Costuma-se atribuir qualquer expressão diferente do alemão-padrão à influência do português, mas com isso, ignoram-se os aspectos herdados diretamente dos dialetos alemães originais, que também possuem desvios sistemáticos às regras gramaticais do alemão-padrão. ${ }^{19}$ Embora sejam muito interessantes, não trataremos aqui desses aspectos dialetais herdados do hunsrückisch, pois neste artigo nos interessa a integração com $o$ português. ${ }^{20}$ A principal característica do "alemão" falado no Brasil não são as suas variações dialetais e os desvios em relação ao alemão-padrão, mas sim a sua caracterização como língua mista e genuinamente brasileira, no que diz respeito ao status.

No dialeto francônio-renano aparecem fenômenos que também se fazem presentes no hunsrückisch. O interessante é que tais fenômenos ocorrem também com palavras do português, que são utilizadas no lugar de suas correspondentes em alemão. A apócope (queda de um ou mais fonemas em início ou fim de palavras) é um fenômeno do dialeto alemão que surge freqüentemente nas variantes do Rio Grande do Sul, como mostra os exemplos seguintes ${ }^{21}$ :

- No início da palavra: cai o [a] da palavra "abacaxi” [a'bakaji] do português e passa para bacaxi ['bakafi] (nhd ${ }^{22}$. Ananas).

- No fim da palavra: cai o [e] da palavra "bonde" ['bondzi] do português e passa a bond ['bont] (nhd. Straßenbahn)

- Concomitantemente no início e no fim da palavra: caem o [e] e o [a] da palavra "espoleta" [ispo'lete], que passa, assim, para spolet ['Jpolet] (nhd. Zünder)

Além da apócope, podemos citar ainda outros fenômenos lingüísticos. Algumas vezes eles ocorrem ao mesmo tempo, isto é, numa mesma palavra, como no exemplo dado por Ziegler com o vocábulo "abóbora" [a'bobore] da língua portuguesa (nhd. Kürbis). Primeiramente, ela passa a bobor (apócope: a vogal inicial e vogal final caem); depois, a consoante [b] varia, de acordo com a tendência no meio de palavra, para [v]

\footnotetext{
${ }^{19}$ Vide Ziegler 1996

${ }^{20}$ Para uma descrição mais detalhada do dialeto alemão, vide Tornquist 1997, Ziegler 1996 ou Altenhofen 1996

${ }^{21}$ Os exemplos citados foram recolhidos pela autora, quando de seu levantamento em uma região teutobrasileira, mas são também retirados de Tornquist (1997), Ziegler (1996) e Altenhofen (1996). Mais exemplos e casos específicos são abordados mais abrangentemente nos seus respectivos livros.

${ }^{22}$ Neuhochdeutsch = Novo Alemão-Padrão
} 
(['bovor]); num próximo passo, o [o] passa para [e] (['bover]) e, como também ocorre no alemão-padrão, o [er] no fim de palavras é pronunciado como um tipo de $\langle a\rangle-$ a saber [e]. Conclusão: o que inicialmente fora tomado por empréstimo como "abóbora", é denominado no hunsrückisch como produto final de bova ['bove].

A formação de palavras com empréstimos é um processo freqüentemente utilizado e caracteriza o hunsrückisch. No português, temos a palavra "balcão", que no alemão é chamado de Theke ou Ladentisch. Os imigrantes e seus descendentes utilizam a variante do português com pronúncia alemã, pronunciando balkón (o que no alemão-padrão remete à "varanda"). Uma vez assimilada no vocabulário, composições com essa palavra, também com palavras alemãs, tornam-se possíveis. O menino que atende no balcão, em alemão Ladengehilfe, é chamado, então, em hunsrückisch, de Balkonjunge.

Tais formações híbridas no hunsrückisch são freqüentes. Em alemão é mais corrente fazer composições, ou seja, formar uma palavra a partir de dois outros lexemas, o que no português é mais raro de acontecer. O fenômeno do alemão ocorre, porém, em hunsrückisch com as duas línguas concomitantemente. Por exemplo, Gebäck / Keks são palavras não empregadas na variante rio-grandense, e que são substituídas por uma correspondente do português: "doce" ['dosi] (pronunciada pelos teuto-brasileiros como ['tos]). Conseqüentemente, Butterkeks ou Weihnachtsgebäck, passam, no hunsrückisch, respectivamente para Puttertos e Weihnachtstos.

O mesmo caso ocorre também com morfemas alemães unidos a lexemas do português:

- Lexema português + sufixo ou prefixo alemão

O sufixo alemão -er denomina, dentre outros, seres humanos de sexo masculino. A palavra portuguesa "caboclo" (nhd. Mischling) recebe uma especificação alemã através desse sufixo e passa a Cabocler. Um verbo para isso pôde, da mesma forma, ser criado pelos falantes de hunsrückisch no Brasil, o qual originou-se do vocábulo brasileiro "caboclo" e de um prefixo alemão: vercaboclern significa tornar-se caboclo, misturar-se etnicamente.

- Lexema português + forma flexional do alemão

No Rio Grande do Sul, os adultos chamam o menino de "guri". O plural dessa palavra é formado, em português, com o $-s$, a única forma de plural produtiva existente na língua portuguesa. Em hunsrückisch, porém, é usada uma forma alemã de plural. Os "guris" são, nessa variante, Gurie.

Também as flexões verbais são utilizadas nessas formações. O verbo alemão umrühren é substituído pelo correspondente português "misturar". No hunsrückisch no Brasil, o infinitivo do verbo é, contudo, misturieren, ou seja, foi usada a terminação alemã. Tais verbos continuam respeitando a conjugação alemã, apesar da raiz portuguesa, pois a forma do infinitivo mantém sua flexão: misturiere, misturiest, misturiert... Um caso típico é a expressão Es chegt! (nhd. Es reicht!), vindo diretamente do português "Chega!", mantendo a estrutura e a flexão alemãs.

Com freqüência são usadas palavras do português quando as correspondentes em alemão não são conhecidas. Isso ocorre com a denominação de objetos que ainda não existiam quando da emigração, ou de objetos específicos que não havia na Alemanha na época. Esses termos são chamados cientificamente de "estrangeirismos". Um exemplo para o primeiro caso é a palavra "televisão". Na época da emigração, a televisão ainda não havia sido inventada, e por isso, os falantes de hunsrückisch utilizam a palavra portuguesa para o objeto, uma vez que Fernseher não pertence ao seu vocabulário. Um 
exemplo para o segundo caso de estrangeirismo no hunsrückisch é a palavra "gaúcho". Como os imigrantes só passaram a conhecer um gaúcho depois da vinda para o Brasil, não existia ainda uma denominação para esse indivíduo na terra natal, e os colonos tiveram que lançar mão da palavra usada no Brasil.

A assimilação de tais estrangeirismos do português é provavelmente o processo mais comum no hunsrückisch, pois continuamente surgem novos elementos para serem nomeados, ou palavras mais antigas caem em desuso. Poder-se-ia fazer uma lista imensa de palavras do português já enraizadas no hunsrückisch, como "cueca" (Slip), "hidratante" (Körpermilch), "modess" 23 (Damenbinde)... Isso, entretanto, não significa que novos elementos ganhem automaticamente uma denominação em língua portuguesa. Algumas vezes os colonos criam nomes para objetos com o vocabulário alemão (ou teuto-brasileiro) já existente, mesmo que se configure uma tradução do português. Por exemplo, para Kakao não foi usada a variante portuguesa (chocolate em pó, achocolatado), mas foi criado o termo Schokolodemehl, a partir das palavras alemãs Schokolade (chocolate) e Mehl (farinha).

Apesar de influências fonéticas, morfológicas, semânticas e pragmáticas, a maior "mistura", o maior número de empréstimos no hunsrückisch, aparece realmente no campo lexical. Willems, por exemplo, catalogou em uma de suas obras 693 palavras germanizadas, ou seja, emprestadas do português e adaptadas foneticamente ao alemão. ${ }^{24}$ A partir das minhas observações, coletei algumas dessas palavras germanizadas, que pertencem ao dia-a-dia dos colonos. Cito algumas delas na seguinte ordem: 1hunsrïckisch; 2- português; e entre parênteses a tradução alemã atual.

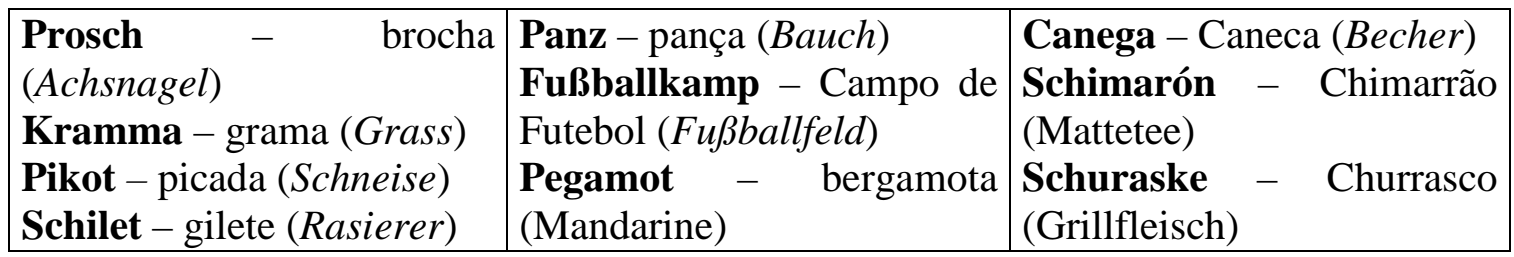

Terminamos essa parte com uma citação interessante, já muitas vezes utilizada por pesquisadores da área. ${ }^{25}$ Ela é tida como uma "frase típica" do hunsrückisch no Brasil. Apesar do caráter estereotipado, reproduzimo-la a título de ilustração, dando a tradução para o português e apresentando a correspondente no alemão-padrão atual, para que possam ser feitas comparações com os lexemas empregados:

\section{De Man hat de mula mit de rehle dorich de banhado in das potrea getockt}

[Der Mann hat den Esel mit der Peitsche durch den Sumpf auf die Weide getrieben]

(O homem tocou ${ }^{26}$ a mula com o relho através do banhado para o potreiro).

\footnotetext{
${ }^{23}$ Embora o termo "modess" seja, na verdade, o nome de uma marca. Como é, porém, utilizado metonimicamente de forma generalizada para "absorvente" em todo o Brasil, ou seja, é um lexema extremamente produtivo, foi emprestado do português para designar o objeto também em hunsrückisch. ${ }^{24}$ Vide Willems 1980, 198-214

${ }^{25}$ Pr exemplo, Ziegler 1996, 73

${ }^{26}$ É de se destacar, que o verbo tocken do hunsrückisch (radical do português "tocar" + desinência verbal alemã -en) segue inteiramente a flexão da gramática alemã; o passado (Perfekt), da mesma forma, é constituído de "verbo auxiliar + frase + estrutura do particípio (ge + raiz verbal + t)", como no alemão padrão.
} 


\section{Conclusão}

Os imigrantes não fizeram nada para manter a sua língua intacta, pois fazia parte de um processo natural e inconsciente de desenvolvimento lingüístico e, neste caso, de integração lingüístico-identitária. O hunsrückisch é, na verdade, uma comprovação para isso. Através dessa língua - que constitui uma variante peculiar e um patrimônio lingüístico-cultural imaterial brasileiro - fica claro que, submetido a interferências externas, o idioma sofreu mudanças lingüísticas, processo comum e natural a todas as línguas vivas. Nesse caso, especificamente, a evolução da língua para o produto final atual foi possível graças ao contato com outras línguas, mas não resultou apenas disso, como já afirmado no texto.

O português se impôs com o tempo tão fortemente nas colônias, que os descendentes entre si também se deixaram (e se deixam) influenciar pelo idioma português. Fora das comunidades eles falam o português - atualmente todos já o falam sem restrições como uma de suas línguas maternas -, mas essa língua os acompanha agora até em casa, na família e no seu hunsrückisch. Pode até ser que em outras áreas queira-se dizer que não se percebeu integração das comunidades "fechadas" na sociedade brasileira, contudo, através do hunsrückisch - que ainda sofre contínuo processo de modificação - nota-se essa integração.

Se compararmos o número de falantes do alemão-padrão, hunsrückisch e de português nas colônias alemãs ao longo desses anos de história no Brasil, perceber-se-á a diminuição considerável dos falantes de alemão-padrão (apenas os avós da atual geração tiveram aulas deste idioma), o aumento a praticamente $100 \%$ de domínio do português (os avós da atual geração não o dominavam, eram praticamente passivos na língua) e, apesar de uma queda no número de falantes do hunsrückisch, cada vez mais elementos do português entram na variante falada no Brasil. O que para muitos, então, pode parecer um corrompimento do hunsrückisch, se mostra, na nossa opinião, como resultado de um processo natural lingüístico enriquecedor, decorrente, inclusive, de um processo de integração. A mistura ao longo desses 180 anos não foi somente de elementos da língua, mas também de identidade, de aspectos culturais. Afinal, só é possível haver contato linguiístico se há contato social, e só há contato social se há alguma forma de integração.

Embora intimamente ligada a ela, a geração atual percebe que sua língua materna está em um patamar emocional/familiar, já que se configura de maneira tão própria para um indivíduo, sua família e sua comunidade, sendo caracterizada assim, cada vez mais, como "socioleto" ou "familioleto"27. Ela liga com o "lar" (a colônia, os pais) e ainda é entendida como aspecto identitário - pessoal, não nacional. Sem negar a herança da germanidade, esses brasileiros tiveram (e têm) como língua materna uma língua de integração.

\footnotetext{
${ }^{27}$ Essas são formações analógicas a partir do conceito "idioleto" ("Variante dialetal individual, que é percebida em cada falante no menor e mais distante lugarejo de forma única" - Wandrunszka 1979, 38 tradução da autora). "Socioleto" seria, por exemplo, segundo Wandruszka $(1979,27)$ a linguagem diária, informal e corrente de um grupo específico. O conceito "familioleto" foi usado pela primeira vez por Clyne 1968, 84, e refere-se a uma forma lingüística característica e peculiar a uma família (Apud Tornquist 1997, 35).
} 
ALTENHOFEN, Cléo Vilson. Hunsrückisch in Rio Grande do Sul. Ein Beitrag zur Beschreibung einer deutschbrasilianischen Dialektvarietät im Kontakt mit dem Portugiesischen. Stuttgart, Steiner, 1996.

DREHER, Martin Norberto. Igreja e germanidade. São Leopoldo, Sinodal, 1984.

HUBER, Valburga. Saudade e esperança - o dualismo do imigrante alemão refletido em sua literatura. Blumenau, FURB, 1993.

NEUMANN, Gerson Roberto. A "Muttersprache" (língua materna) na obra de Wilhelm Rotermund e Balduíno Rambo e a construção de uma identidade cultural híbrida no Brasil. Rio de Janeiro, Faculdade de Letras, 2000. (Dissertação de Mestrado na Universidade Federal do Rio de Janeiro)

PELOSO, Silvano. Identidade nacional e sociedade multicultural. In: Anais do II Congresso Brasileiro de Professores de Alemão. São Leopoldo, ABRAPA, 1991.

ROCHE, Jean. A colonização alemã e o Rio Grande do Sul - I e II. Porto Alegre, Globo, 1969.

RÜRUP, Reinhard. Deutschland im 19. Jahnhundert: 1815 - 1871. Göttingen, Vandenhoeck und Ruprecht, 1984.

SCHADEN, Egon / WILLEMS, Emílio / HEHL NEIVA, Arthur. Critérios para a conceituação das colônias sob o ponto de vista de seu êxito ou insucesso. In: I Colóquio de Estudos TeutoBrasileiros. Porto Alegre, Faculdade de Filosofia da UFRGS, p. 356-358, 1963.

SEYFERTH, Giralda. Nacionalismo e identidade étnica. Florianópolis, Fundação Catarinense de Cultura, 1981.

A Identidade teuto-brasileira numa perspectiva histórica. In: Mauch, Cláudia / Vasconcellos, Naira [Ed.] Os alemães no sul do Brasil. Canoas, Ed. ULBRA, 1994. TORNQUIST, Ingrid Margareta. "Das hon ich von meiner Mama" - zu Sprache und ethischen Konzepten unter Deutschstämmigen in Rio Grande do Sul. Uppsala, Umeå, 1997. WANDRUSZKA, Mario. Die Mehrsprachigkeit des Menschen. München: Piper, 1979.

WILLEMS, Emilio. Assimilação e populações marginais no Brasil: estudo sociológico dos imigrantes germânicos e seus descendentes. São Paulo, Companhia Editora Nacional, 1940.

WILLEMS, Emílio. A Aculturação dos Alemães no Brasil. Estudo antropológico dos imigrantes alemães e seus descendentes no Brasil. $2^{\circ}$ ed., il., rev. e ampl. São Paulo, Ed. Nacional, 1980.

ZIEGLER, Arne. Deutsche Sprache in Brasilien - Untersuchungen zum Sprachwendel und zum Sprachgebrauch der deutschstämmigen Brasilianer in Rio Grande do Sul. Essen, Die blaue Eule, 1996. 